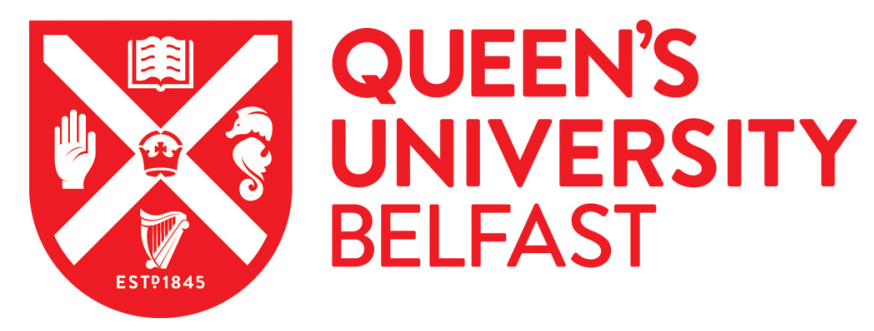

\title{
Dendrons with spermine surface groups as potential building blocks for nonviral vectors in gene therapy
}

Hardy, JG., Kostiainen, MA., Smith, DK., Gabrielson, NP., \& Pack, DW. (2006). Dendrons with spermine surface groups as potential building blocks for nonviral vectors in gene therapy. Bioconjugate Chemistry, 17(1), 172-178. https://doi.org/10.1021/bc050212r

Published in:

Bioconjugate Chemistry

Document Version:

Early version, also known as pre-print

Queen's University Belfast - Research Portal:

Link to publication record in Queen's University Belfast Research Portal

Publisher rights

Copyright @ 2006 American Chemical Society

\section{General rights}

Copyright for the publications made accessible via the Queen's University Belfast Research Portal is retained by the author(s) and / or other copyright owners and it is a condition of accessing these publications that users recognise and abide by the legal requirements associated with these rights.

Take down policy

The Research Portal is Queen's institutional repository that provides access to Queen's research output. Every effort has been made to ensure that content in the Research Portal does not infringe any person's rights, or applicable UK laws. If you discover content in the Research Portal that you believe breaches copyright or violates any law, please contact openaccess@qub.ac.uk. 


\title{
Dendrons with Spermine Surface Groups as Potential Building Blocks for Nonviral Vectors in Gene Therapy
}

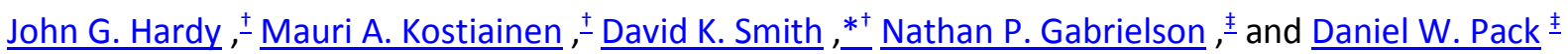
Department of Chemistry, University of York, Heslington, York, YO10 5DD, UK, and Department of Chemical and Biomolecular Engineering, University of Illinois at Urbana Champaign, Urbana, Illinois 61801

\begin{abstract}
This paper investigates a series of dendrons based on the Newkome dendritic scaffold that displays a naturally occurring polyamine (spermine) on their surface. These dendrons have previously been shown to interact with DNA in a generation dependent manner with the more highly branched dendrons exhibiting a strong multivalency effect for the spermine surface groups. In this paper, we investigate the ability of these dendrons to transfect DNA into cells (human breast carcinoma cells, MDA-MB-231, and murine myoblast cells, $\mathrm{C2C12}$ ) as determined by the luciferase assay. Although the dendrons are unable to transfect DNA in their own right, they are capable of delivering DNA in vitro when administered with chloroquine, which assists with escape from endocytic vesicles. The cytotoxicity of the dendrons was determined using the XTT assay, and it was shown that the dendrons were nontoxic either alone or in the presence of DNA. However, when administered with DNA and chloroquine, the most highly branched dendron did exhibit some cytotoxicity. This paper elucidates the relationship between in vitro transfection efficiency and toxicity. While transfection efficiencies are modest, the low toxicity of the dendrons, both in their own right, and in the presence of DNA, provides encouragement that this type of building block, which has a relatively high affinity for DNA, will provide a useful starting point for the further synthetic development of more effective gene transfection agents.
\end{abstract}

\section{Introduction}

The introduction of genetic material into cells (gene transfection) ( 1 ) has the potential to treat a wide variety of diseases such as those that are characterized by a single mutation at a well-defined position on the genome, for example muscular dystrophy (2) and cystic fibrosis ( $\underline{3})$. Gene therapy is also being investigated to treat a range of other diseases, including cancer (4) and AIDS (ㅁ), with the aim being to introduce genetic material into the affected cells and ultimately lead to their destruction. The key problem in gene therapy is the delivery of genetic material to the required cells within a patient. Ex vivo methods involve the removal, genetic modification, and readministration of the patient's cells. The ex vivo approach enables well controlled localized delivery but has a number of limitations such as being labor intensive, requiring special production facilities, and only being applicable for accessible and robust cells. More interesting, however, is the development of in vivo gene therapies, and with this goal in mind, the development of novel vectors for gene delivery capable of navigating a series of extra- and intracellular barriers is of crucial importance. Vectors fall into two main categories, viral and nonviral (synthetic) vectors. Viruses are naturally evolved vectors, in which part of the virus' genome is replaced with therapeutic genetic material (ㅁ). Although viral vectors are efficient gene delivery systems and have been utilized in the majority of clinical trials, there have been a number of problems with their application in human gene therapy, including poor targeting to cells, expensive production, and immunogenic and pathogenic responses. Nonviral vectors rely on the ability of synthetic systems to bind and condense the genetic material effectively (ㄱ). Cationic liposomes (으) (normally used in the presence of a helper lipid) are quite efficient, even in vivo, and there is good potential for synthetic modification of this class of delivery agent. However, they tend to be relatively unstable and toxic and often lack cell-specific targeting 
ability. Cationic polymers $(\underline{9})$ are cheap and simple to modify in order to impart desirable properties such as degradation under certain conditions and cell-specific targeting.

In the last 10 years, there has been an explosion of interest in using dendrimers (10) (highly branched monodisperse polymers) as vectors. Their transfection ability is comparable to polymers, but many of them exhibit reduced toxicity. The commercially available spherical poly(amidoamine) (PAMAM) dendrimers have been extensively studied. It has been shown that fractured (i.e., partially degraded) PAMAMs can be more effective at gene transfection, potentially as a consequence of their greater flexibility and ability to compact DNA (1ㅡ). PAMAM dendrimers have also been synthetically modified in order to improve solubility and cell membrane fusion and reduce toxicity (12). Other spherical dendritic polyamine scaffolds have also been investigated as gene delivery systems, such as those based on a poly(propyleneimine) (PPI) framework (13). Dendritic I-lysine derivatives have been widely exploited (14), and in a number of these cases, dendrons (individual dendritic branches) have been used as DNA binding and gene delivery agents, rather than fully formed spherical dendrimers. The inherent asymmetry of the dendron structure facilitates simple structural modification in a precisely controlled fashion, either at the surface, or at the focal point. This is not possible to the same extent with polymers or spherical dendrimers. The typical 'dendron strategy' is to use a branched molecule with a polycationic surface capable of interacting with the anionic phosphates on DNA and then subsequently functionalize the focal point with a unit capable of either hydrophobic groups which assist the process of membrane fusion (15) or polar groups assisting water solubility and biocompatibility (e.g., poly(ethylene glycol), PEG) (12e).

Spermine, a naturally occurring linear polyamine, is often utilized as the DNA binding portion of nondendritic vectors (16). Indeed, some commercially useful vectors (e.g. Transfectam (17), Genzyme Lipid \#67 (18), and RPR-120535 (19)) incorporate spermine units. Biology itself makes use of simple tetraamines, such as spermine, to achieve DNA binding (20). Although spermine is significantly better than an isolated amine for binding DNA, however, the interaction is still relatively weak and generates a mobile complex. Consequently, spermine struggles to compete with DNAbound inorganic cations (21).

We have recently reported (22) a series of dendrons utilizing the Newkome dendritic scaffold (23) which display multiple spermine groups on the dendritic surface (Figure 1). We demonstrated that these dendrons bind DNA in a generation dependent manner (i.e., $\mathbf{G 0}<\mathbf{G 1}<\mathbf{G 2}$ ), with higher generation dendrons exhibiting binding strengths which were independent of salt concentration. Dendron G2 showed very strong DNA binding, and we could ascribe this to a clear multivalency effect. Some multivalent arrays had been previously reported in which multiple spermine groups were grafted onto dextran polymers (24). However, we wanted to develop multivalent DNA binders with well-defined molecular structures, to enable the construction of structure-activity relationships, as well as developing monodisperse systems, with relatively low molecular weights, which have a greater chance of being licensed for therapeutic use in the longer term. In this new paper, we explore the in vitro transfection efficiency (as determined by luciferase assay) and the toxicity (as determined by XTT assay), using human breast carcinoma cells (MDA-MB-231) and murine myoblast cells (C2C12). Most importantly, using this approach, we identify the optimum unit (G1) which exhibits the greatest potential for future synthetic development as a nonviral vector. 
Caros

Spermine tetrahydrochloride

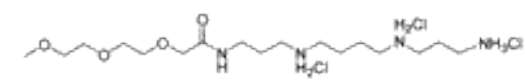

G0

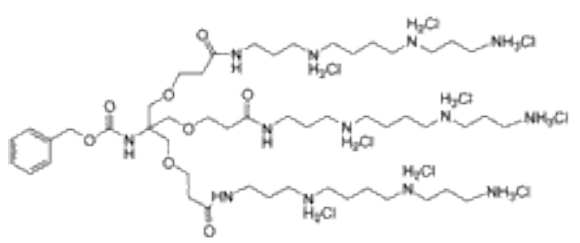

G1

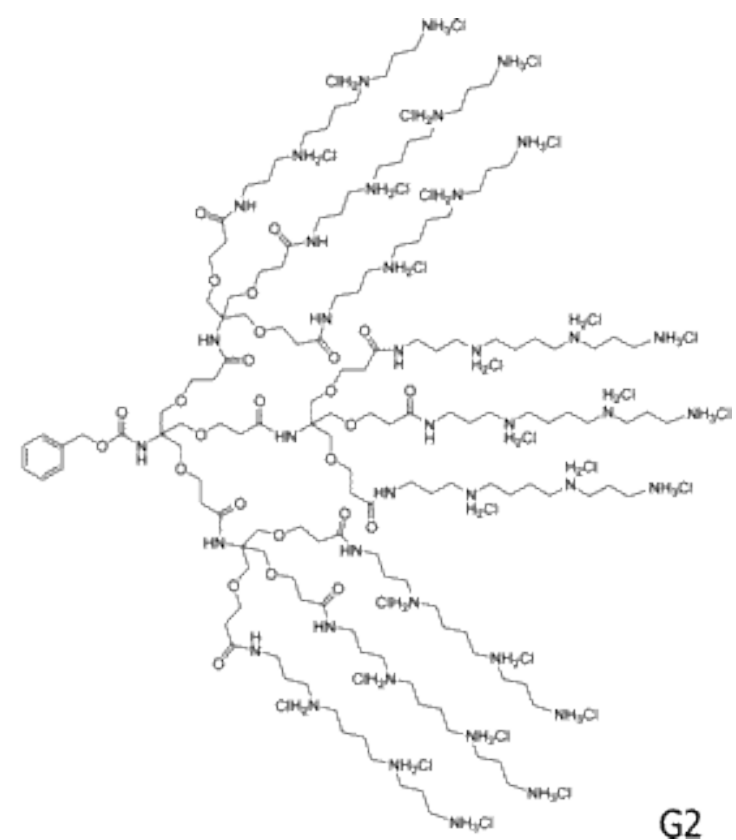

G2

Figure 1 Polyamines based on spermine investigated in this paper for their transfection potential, including dendritic multivalent spermines, $\mathbf{G 1}$ and $\mathbf{G 2}$.

\section{Materials and Methods}

Polyamine Dendrons. The polyamine dendrons with spermine surface groups were synthesized using methods previously reported by us and fully characterized; all data were in agreement with those previously published (22).

Cells and Plasmid DNA. The MDA-MB-231 human breast carcinoma cell line was purchased from the American Type Culture Collection, and the $\mathrm{C} 2 \mathrm{C} 12$ murine myoblast cell line was a gift from Prof. Stephen Kaufman (University of Illinois at Urbana Champaign, IL). All cell lines were maintained according to their respective ATCC protocols at $37{ }^{\circ} \mathrm{C}$ and $5 \% \mathrm{CO}_{2}$ but were adapted from fetal bovine serum to heat-inactivated horse serum. The 5.3 kilobase pair expression vector, pGL3 (Promega, Madison, WI), containing the luciferase gene driven by the SV40 promoter and enhancer, was grown in DH5 $\alpha$ E. Coli (Gibco BRL, Rockville, MD) and purified using a commercial plasmid purification kit (Bio-Rad, Hercules, CA). Plasmids were further purified by ethanol precipitation; the ratio of absorbances at 260 and $280 \mathrm{~nm}$ was 1.8 or greater.

Gel Retardation Studies. Appropriate amounts of polyamine and DNA plasmid solutions in $150 \mathrm{mM}$ $\mathrm{NaCl}(\mathrm{pH} 7.3,20 \mathrm{mM}$ PIPES as buffer) were added to a further $10 \mu \mathrm{L}$ of $150 \mathrm{mM} \mathrm{NaCl}(\mathrm{pH} 7.3,20 \mathrm{mM}$ PIPES as buffer) to achieve the desired polyamine/DNA ratio. The resultant complexes were incubated at $4{ }^{\circ} \mathrm{C}$ for $15 \mathrm{~min}$. Then, $3 \mu \mathrm{L}$ Blue/Orange $6 \mathrm{X}$ loading dye (Promega, Madison, WI) was added, and the mixtures were incubated at $4{ }^{\circ} \mathrm{C}$ for a further $5 \mathrm{~min}$. After this time, $15 \mu \mathrm{L}$ was electrophoresed on a $0.75 \%$ agarose gel $(70 \mathrm{~V}, 1 \mathrm{~h})$. DNA was visualized with ethidium bromide staining (Bio-Rad, Hercules, CA). Samples were run in duplicate.

Dynamic Light Scattering Studies. DNA-polyamine complexes were prepared at room temperature, by the titration of polyamine solution into a solution of plasmid DNA (1 $\mu \mathrm{g})$ in PBS-buffered Millipore water $(500 \mu \mathrm{L})$ to achieve the desired mass ratios. The volume of polyamine solution added to the DNA solution did not exceed $5 \%$ of the total volume of the solution. Complex size determination was performed by dynamic light scattering on a DynaPro-MS800 particle sizer (Protein Solutions, Lakewood, NJ), and the data were analyzed with Dynamics v6.3 software (Protein Solutions). 
Complex Formation and Transfection. DNA-polyamine complexes were prepared at room temperature in $150 \mathrm{mM} \mathrm{NaCl}$ (pH 7.3, $20 \mathrm{mM}$ PIPES as buffer) by addition of $250 \mu \mathrm{L}$ of polyamine solution to an equal volume of $10 \mu \mathrm{g}$ of plasmid to achieve the desired polyamine/DNA ratio. The resultant complexes were incubated at $4{ }^{\circ} \mathrm{C}$ for $15 \mathrm{~min}$. Cells were cultured in standard growth medium (DMEM supplemented according to ATCC protocols with $10 \%$ horse serum and $1 \%$ penicillin-streptomycin) and plated in 12 -well plates at $1 \times 10^{5}$ cells per well $24 \mathrm{~h}$ before transfection. Immediately before transfection, the growth medium was replaced with serum-free medium, and $50 \mu \mathrm{L}$ of complex ( $1 \mu \mathrm{g}$ of plasmid per well) was added to each well (either with or without chloroquine at a final concentration of $100 \mu \mathrm{M}$ ). Transfection medium was replaced with growth medium $4 \mathrm{~h}$ after transfection. Luciferase expression was quantified $20 \mathrm{~h}$ later using a Promega luciferase assay system $(n \geq 6)$ according to the manufacturer's protocol. Luciferase activity was measured in relative light units (RLU) using a Lumat LB9507 luminometer (Berthold, GMBH, Germany) and converted to luciferase concentration by comparison with recombinant luciferase standards (Promega). Results were normalized to total cell protein as determined using a Bio-Rad protein assay kit.

Cytotoxicity Determinations. Cytotoxicity was characterized as a decrease in metabolic activity using the XTT assay (25). Cells were placed in $96-$ well plates at an initial density of 5000 cells per well in $100 \mu \mathrm{L}$ of growth medium for $24 \mathrm{~h}$, after which time the growth medium was replaced with fresh serum-free medium. At this point a solution of: polyamine alone ( $5 \mathrm{\mu g}$ of polyamine per well), polyamine/DNA complexes ( $1 \mu \mathrm{g}$ of DNA and $5 \mu \mathrm{g}$ of polyamine per well), or polyamine/DNA complexes with chloroquine (effective transfection conditions: $0.2 \mu \mathrm{g}$ of DNA, $1.0 \mu \mathrm{g}$ of polyamine per well, chloroquine at a final concentration of $100 \mu \mathrm{M})$, in $150 \mathrm{mM} \mathrm{NaCl}(\mathrm{pH} \mathrm{7.3,20} \mathrm{mM} \mathrm{PIPES}$ as buffer) was added (volume equal to or less than $10 \mu \mathrm{L}$ ). Cells were incubated for $4 \mathrm{~h}$, and the medium was replaced with complete growth medium for $16 \mathrm{~h}$. Fresh XTT $(1 \mathrm{mg} / \mathrm{mL})$ and the coenzyme $Q_{0}(80 \mathrm{mg} / \mathrm{mL})$ stock were prepared each day in PBS $(0.5 \mu \mathrm{g} / \mu \mathrm{L} \mathrm{XTT}$ and $0.04 \mu \mathrm{g} / \mu \mathrm{L}$ coenzyme $\left.Q_{0}\right)$, and $25 \mu \mathrm{L}$ aliquots were added to each well. The samples were incubated for a further $4 \mathrm{~h}$ at $37^{\circ} \mathrm{C}$, and the absorbance was read at $450 \mathrm{~nm}$ relative to blank well prepared without cells $(n=16)$.

\section{Results}

Gel Retardation Studies. As outlined in the Introduction, we have previously shown the dendrons to be capable of binding plasmid DNA and condensing it into well-defined nanoscale particles. The formation of these polyplexes can be observed as a reduction of mobility in gel electrophoresis (Figure 2). DNA was mixed with increasing amounts of polyamine in order to determine the ability of the polyamine to form complexes with the DNA. Both spermine and the $\mathbf{G 0}$ model compound failed to retard the migration of DNA, even at mass ratios of 1:100 (DNA:polyamine). In contrast, however, dendritic spermine derivatives $\mathbf{G 1}$ and $\mathbf{G} \mathbf{2}$ both effectively retarded the migration of DNA at mass ratios of 1:1 (DNA:polyamine) and above. This highlights the cooperativity of the DNA binding afforded by using a dendritic scaffold for the placement of multiple spermine groups, as discussed in more detail in our previous publication (22). 

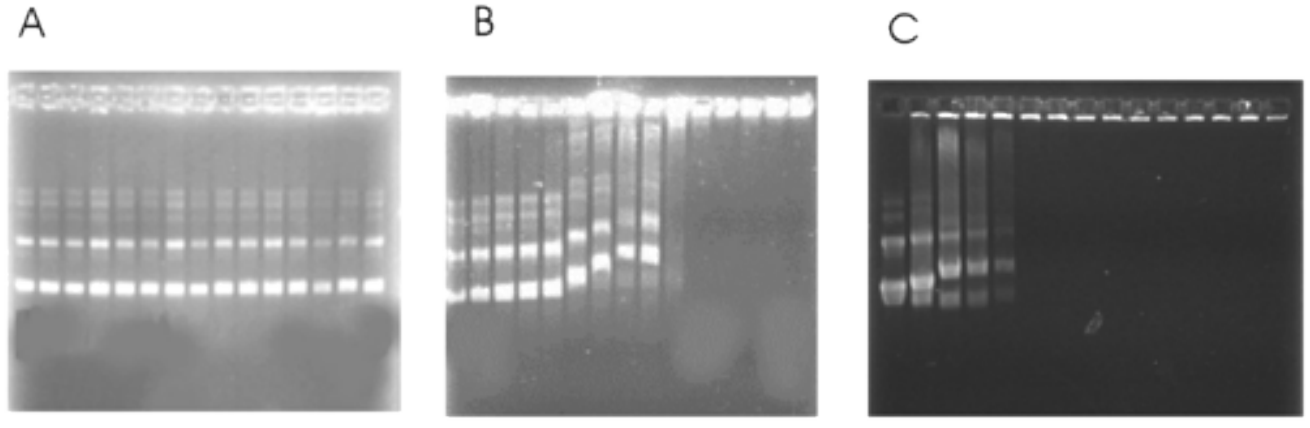

Figure 2 Agarose gel electrophoresis of polyamine/DNA complexes. (A) G0 (polyamine:DNA, w:w): lane 1, 0:1; lane 2, 6:1; lane 3, 7:1; lane 4, 8:1; lane 5, 9:1; lane 6, 10:1; lane 7, 20:1; lane 8, 30:1; lane 9, 40:1; lane 10, 50:1; lane 11, 60:1; lane 12, 70:1; lane 13, 80:1; lane 14, 90:1; lane 15, 100:1. (B and C) G1 and G2 respectively (polyamine:DNA, w:w): lane 1, 0:1; lane 2, 0.1:1; lane 3, 0.2:1; lane 4, 0.3:1; lane 5, 0.4:1; lane 6, 0.5:1; lane 7, 0.6:1; lane 8, 0.7:1; lane 9, 0.8:1; lane 10, 0.9:1; lane 11, 1:1; lane 12, 2:1; lane 13, 3:1; lane 14, 4:1; lane 15, 5:1.

Dynamic Light Scattering Studies. Polyplex size can be a crucial factor for efficient cell uptake, and we therefore investigated the effect of charge ratio on complex size. Complexes with polyamine/DNA ratios of 0:1 to 40:1 (w/w), typical of transfection experiments, were formed, and dynamic light scattering was used to measure complex size. Assuming that spherical aggregates were formed (as observed for $\mathbf{G 1}$ and $\mathbf{G 2}$ with plasmid DNA by transmission electron microscopy [TEM] methods), allowed us to calculate approximate diameters for the aggregates. These studies were performed with plasmid DNA alone, and in the presence of spermine, G0, G1, and $\mathbf{G 2}$. In each case, the experiments were performed at different polyamine:DNA mass ratios in order to see the effect of molar ratio on the aggregate formed. The data are presented in Figure 3. 


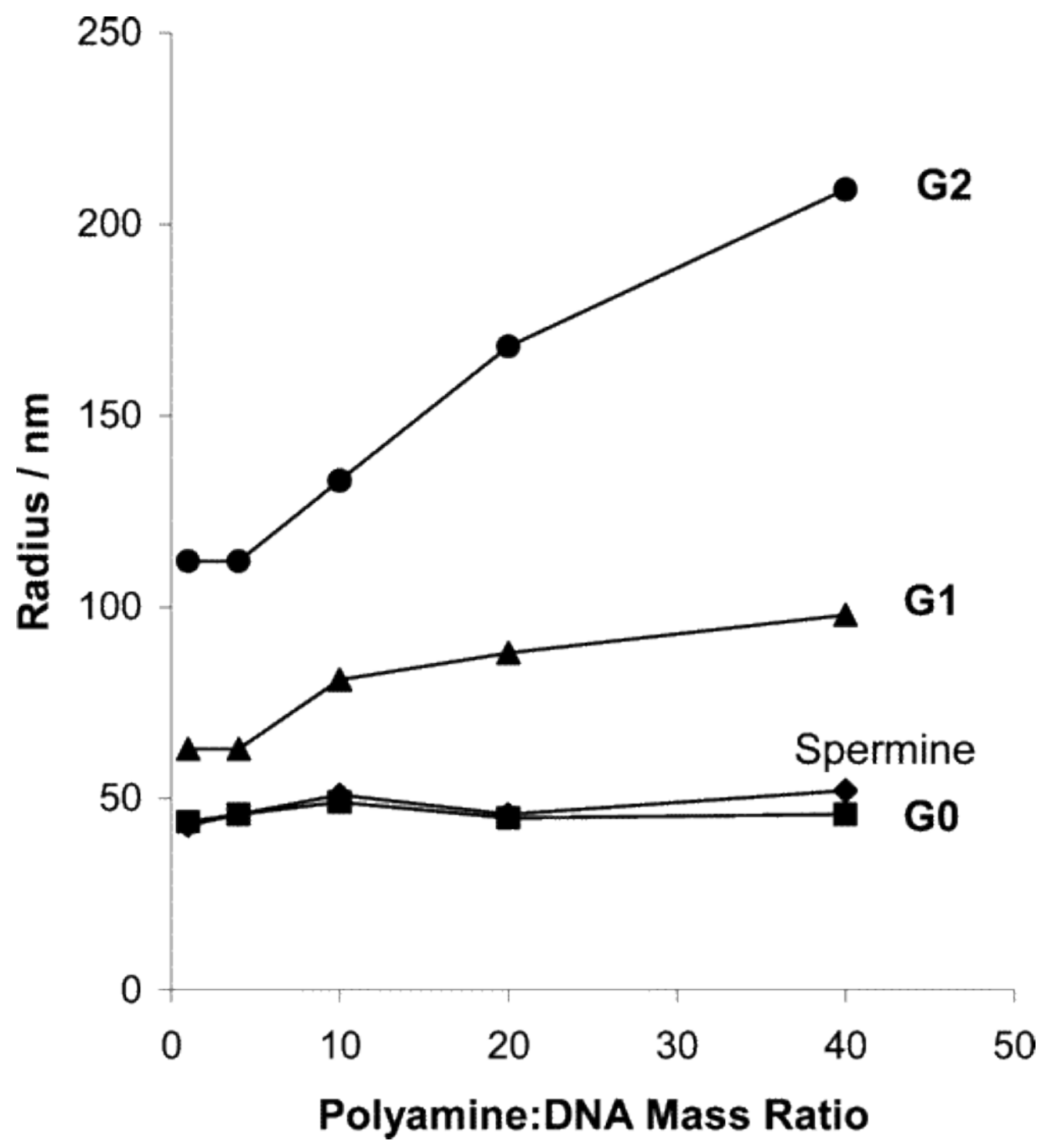

Figure 3 Dynamic light scattering results indicating the polyamine:DNA mass ratio and the approximate dimensions $(\mathrm{nm})$ of the aggregate formed in each case. In the absence of polyamine, light scattering indicated a diameter of $66 \mathrm{~nm}$.

In the absence of DNA, a diameter of $66 \mathrm{~nm}$ was determined for the DNA. Spermine and $\mathbf{G 0}$ had little effect on the dimensions of the system - the diameter of the aggregate remained constant at around $40-50 \mathrm{~nm}$, irrespective of the ratio of polyamine to DNA employed. This is in agreement with previous studies (20a). Dendron $\mathbf{G 1}$ formed significantly larger aggregates in the presence of plasmid DNA. This was particularly true at higher polyamine:DNA mass ratios, where nanoscale complexes of around $100 \mathrm{~nm}$ were present in solution. Previous reports have indicated that complexes in this size range are efficiently endocytosed during transfection (26). The size of the aggregates formed between $\mathbf{G} 2$ and plasmid DNA was significantly larger than that formed between $\mathbf{G 1}$ and DNA, in agreement with the previous TEM studies $(\underline{22})$. Once again, on increasing the polyamine:DNA mass ratio, the diameter of these complexes increased significantly (to over $200 \mathrm{~nm}$ ).

Complex Formation and Transfection. Our groups are interested in the utilization of gene therapy for the treatment of cancer (4) and muscular dystrophy (2); hence, we investigated the efficacy of the polyamine dendrons in gene delivery to human breast carcinoma cells (MDA-MB-231) and murine myoblasts (C2C12). Both cell lines were transfected in vitro with $1 \mu \mathrm{g}$ of plasmid DNA per 100000 cells. In each case, the DNA was complexed with varying amounts of different polyamines. Gene transfection efficiency was measured as luciferase enzyme activity and normalized to total cell 
protein. Initially, the dendrons were investigated in their own right to determine their ability to transfect DNA into cells and allow expression of luciferase. However, no measurable transfection could be observed in any case.

However, in the presence of chloroquine (at a final concentration of $100 \mu \mathrm{M}$ ) measurable gene transfection was observed with some of the spermine derivatives (Figure 4). Chloroquine is widely used as a 'helper molecule' for gene transfection (27). Although the mechanism of action is not fully understood, it has been argued that chloroquine is a weak endosomotropic buffer, raising the endosomal $\mathrm{pH}$, resulting in an increase in osmolarity and consequent endosome lysis. In this way chloroquine assists the escape of transfected DNA from the endosome. The nondendritic molecules (i.e., spermine and $\mathbf{G O}$ ) induced no measurable gene expression over the range of polyamine:DNA mass ratios investigated (1:1 and 4:1). However, some transfection and subsequent luciferase expression was observed for the dendritic spermine derivatives in combination with chloroquine. At low polyamine:DNA mass ratios (1:1 and 4:1), the second generation dendron was significantly better at transfection than the first generation analogue. However, at higher polyamine:DNA mass ratios (10:1 and 20:1) the transfection efficiency of the second generation dendron was observed to decrease sharply. Under equivalent conditions, the transfection efficiency of the first generation analogue $\mathbf{G 1}$ increased dramatically. Indeed, $\mathbf{G 1}$ became more effective at transfection than $\mathbf{G} \mathbf{2}$ at high polyamine:DNA mass ratios. A similar trend was observed for both cell lines, although the transfection into murine myoblasts $\mathrm{C} 2 \mathrm{C} 12$ was higher than that for the human breast carcinoma cells (MDA-MB-231).

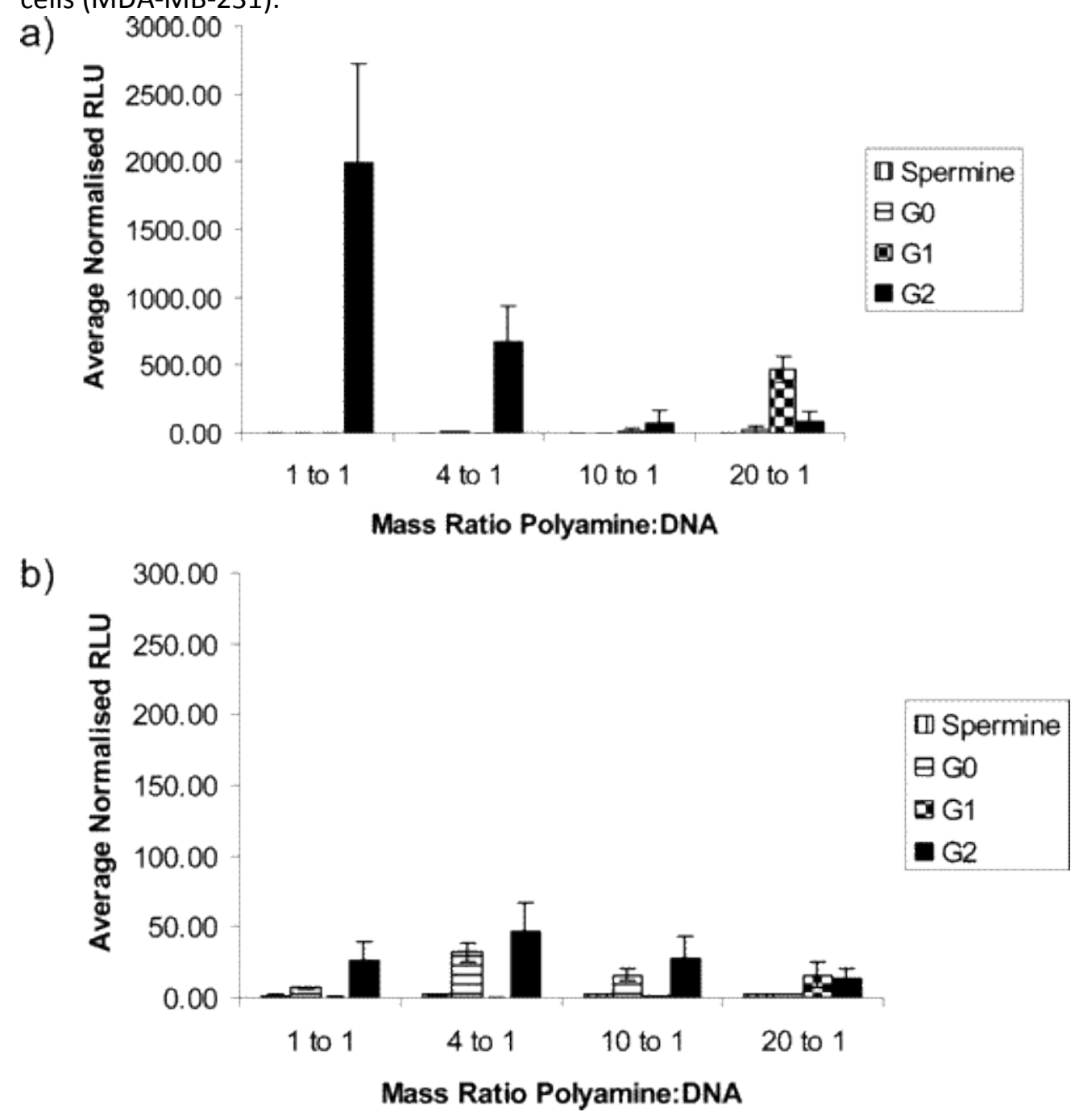


Figure 4 Transfection efficiency of spermine, the nondendritic model (G0), and the dendrons displaying spermine on the surface (G1 and G2) in (a) C2C12 and (b) MDA-MB-231 cells. Luciferase expression was normalized by total cellular protein, i.e., data are given in RLU/mg of protein. $(N=6$, error bars represent standard deviation). Transfection is performed in the presence of chloroquine $(100 \mu \mathrm{M})$.

Cytotoxicity Determination. Polycationic molecules have been reported to damage cell membranes as a result of the electrostatic attraction of polycations to the plasma membrane, whereas neutral and anionic polymers cause minimal damage to cellular membranes. With this potential drawback of polycationic vectors firmly in mind, we assayed the cytotoxicity of our dendrons using an XTT assay (25). Human breast carcinoma cells (MDA-MB-231) and murine myoblasts (C2C12) were exposed to various conditions (i.e., polyamine, polyamine+DNA, polyamine+DNA+chloroquine) for $4 \mathrm{~h}$, and metabolic activity was assayed $20 \mathrm{~h}$ later. The results of these studies are collected in Table 1.

Table 1. Cytotoxicity of Spermine, the Nondendritic Model (G0), and First (G1) and Second (G2) Generation Dendrons, as well as Poly(ethyleneimine) (PEI) in Murine Myoblast C2C12 and Human Breast Carcinoma MDA-MB-231 Cells ${ }^{a}$

\begin{tabular}{llllllll} 
& & \multicolumn{3}{c}{ metabolic activity (relative to 1.000) } \\
cell line & conditions & spermine & G0 & G1 & G2 & PEI & CQ $^{b}$ \\
C2C12 & no polyamine & & & & & & 0.512 \\
C2C12 & polyamine alone & 0.980 & 1.000 & 1.070 & 1.006 & 0.705 & \\
C2C12 & polyamine + DNA & 1.659 & 1.032 & 1.032 & 1.015 & 0.808 & \\
C2C12 & polyamine + DNA + chloroquine & 0.758 & 0.968 & 1.238 & 0.305 & & \\
MDA-MB-231 & no polyamine & & & & & & \\
MDA-MB-231 & polyamine alone & 1.022 & 1.070 & 1.003 & 0.997 & 0.878 & \\
MDA-MB-231 & polyamine + DNA & 1.099 & 1.063 & 1.011 & 1.034 & 0.954 & \\
MDA-MB-231 & polyamine + DNA + chloroquine & 0.886 & 0.979 & 0.988 & 0.398 & &
\end{tabular}

${ }^{a}$ Cytotoxicity is reported as the effective metabolic activity, using an XTT assay. In each case, the metabolic activity of a blank sample of cells (i.e. untreated by polyamine, DNA, or chloroquine) was taken as $1.000^{b} \mathrm{CQ}=$ chloroquine; concentration $=100 \mu \mathrm{M}$.

No reduction in metabolic activity was observed when the polyamine alone was added at a concentration of $1 \mu \mathrm{g}$ per 1000 cells. The one exception to this was when a polyamine control ( 25 kDa poly(ethyleneimine)) was employed, in which case the observed metabolic activity was reduced by $30 \%$ for the $\mathrm{C} 2 \mathrm{C} 12$ cells. This is important as it indicates that our dendrons are significantly less cytotoxic than PEI. Similarly, when a combination of polyamine and DNA was added to the cells (0.2 $\mu \mathrm{g}$ DNA and $1 \mu \mathrm{g}$ polyamine per 1000 cells), our dendrons (G1 and G2) had no observable cytotoxicity. However, once again, the $25 \mathrm{kDa}$ PEI control reduced metabolic activity, this time by $20 \%$ for the $\mathrm{C} 2 \mathrm{C} 12$ cells.

Significant cytotoxicities, however, were observed in the presence of chloroquine, under experimental conditions identical to those in which transfection had been performed (i.e., $0.01 \mu \mathrm{g}$ DNA and $0.1 \mu \mathrm{g}$ polyamine per 1000 cells, and chloroquine at a final concentration of $100 \mu \mathrm{M}$ ). Under these conditions, chloroquine and DNA reduced metabolic activity by $50 \%$ (even in the absence of polyamines). In the presence of chloroquine, DNA, and either spermine, G0, or G1, the cells actually exhibited greater metabolic activities than they did in the absence of the polyamine. Indeed, in the presence of $\mathbf{G 0}$ or $\mathbf{G 1}$, the metabolic activity of the cells was effectively normal. However, using chloroquine and DNA in the presence of $\mathbf{G} \mathbf{2}$ gave rise to a marked reduction in 
metabolic activity (ca. $70 \%$ for $\mathrm{C} 2 \mathrm{C} 12$ cells). In all cases, the MDA-MB-231 cells were found to be more robust, and the polyamines and chloroquine were found to have smaller effects on the metabolic activity than they do for $\mathrm{C} 2 \mathrm{C} 12$ cells.

\section{Discussion}

For effective transfection, plasmid DNA must be effectively bound and condensed under biological conditions (i.e., high salt concentrations, relevant $\mathrm{pH}$ values). We have previously shown that dendritic molecules $\mathbf{G} \mathbf{1}$ and $\mathbf{G} \mathbf{2}$ can do this very effectively. We previously used ethidium bromide displacement assays to determine that the DNA binding strength was very low for the nondendritic systems (i.e., spermine and $\mathbf{G} \mathbf{0}$ ) and significantly higher for $\mathbf{G 1}$ and $\mathbf{G 2}$. Indeed, for $\mathbf{G} \mathbf{2}$ the binding of DNA was independent of salt concentration. The detailed gel retardation assays reported in this paper indicate that condensation of the DNA occurs from polyamine:DNA mass ratios of 1:1 and greater for $\mathbf{G 1}$ and $\mathbf{G 2}$. Our previous TEM studies indicated that the G1:DNA complexes were approximately spherical and 100-150 nm in diameter. The G2:DNA complexes, however, were significantly larger (ca. $400 \mathrm{~nm}$ ). In this paper, we have used light scattering methods to provide further evidence for the dimensions of the polyplexes formed between polyamines and DNA in solution. The results from these studies are in approximate agreement with the dimensions as visualized using TEM methods. Assuming the formation of spherical polyplexes, $\mathbf{G} 1$ was calculated to form a polyplex with a diameter of up to $100 \mathrm{~nm}$, while $\mathbf{G} \mathbf{2}$ once again formed larger polyplexes up to approximately $210 \mathrm{~nm}$.

The results from the in vitro tests reported in this paper indicate that the dendrons are ineffective transfection agents in their own right. This is clearly not due to an inability to condense the DNA effectively, and we postulate that transfection may fail due to an inability of the polyplex to escape from endocytic vesicles. This postulate is supported by the observation that in the presence of chloroquine the transfection efficiencies improved significantly. Spermine itself is almost completely protonated at physiological $\mathrm{pH}$, and it is therefore possible that these constructs have limited capacity to act as proton sponges and buffer the endosome (a process associated with endosomal escape). Therefore chloroquine is required to enable the escape process. In this way, we propose that these dendritic spermine derivatives behave more like polylysine than proton sponge polymers such as PEI or PAMAM. One aspect of future work will focus on improving the ability of these dendritic constructs to cross cell membranes and escape from endosomes even in the absence of chloroquine. It should also be noted that an alternative postulate is that the polyplexes are so strongly bound that they are unable to release the DNA once within the cell.

In the presence of chloroquine, the nondendritic molecules (spermine and $\mathbf{G O}$ ) are ineffective nonviral vectors for DNA. This is presumably because they fail to bind and condense DNA effectively (as shown by our previous ethidium bromide displacement assays and the gel electrophoresis reported in this paper). Dendron $\mathbf{G 1}$ generally improved in its transfection efficiency on increasing the polyamine:DNA mass ratio. At low mass ratios, dendron $\mathbf{G} \mathbf{2}$ was significantly more effective than G1. However, on increasing the mass ratio, the transfection efficiency achieved by $\mathbf{G} \mathbf{2}$ was observed to drop significantly, and $\mathbf{G 1}$ became the more effective transfection agent. We argue that this decrease in transfection efficiency observed with $\mathbf{G} 2$ is a consequence of its toxicity when administered in the presence of chloroquine (Table 1). Dendron $\mathbf{G 1}$ on the other hand has no significant toxicity in the presence of chloroquine and therefore became more effective than $\mathbf{G} \mathbf{2}$ at high polyamine:DNA mass ratios. In this way, the results from our toxicity assay support the observed delivery results.

It must be noted here that even in the presence of chloroquine, the transfection efficiencies observed are too low for these structures to have clinically significant activity in vivo. In fact, 
transfection efficiencies would need to be improved by several orders of magnitude. The observed efficiencies are in line with low molecular weight poly(amidoamine) (PAMAM) dendrimers (11), which only form complexes with DNA at high N/P ratios. In general terms, an increase in molecular weight for PAMAMs yields a significant increase in transfection efficiency, and the same trend may be expected for higher molecular weight analogues of our dendrons. However, it is also possible to make other significant structural modifications to the structure of dendrons $\mathbf{G 1}$ and $\mathbf{G} \mathbf{2}$ which might be expected to enhance transfection efficiencies and would avoid the tedious and time-consuming syntheses required for higher generation dendritic molecules. Work to generate simple synthetically modified versions of our nontoxic dendrons is currently underway.

\section{Conclusions}

In summary, this paper has investigated the ability of our new simple dendron structures, functionalized on the surface with multiple spermine groups, to act as vectors in gene therapy. It has been shown that the dendrons can transfect DNA in the presence of chloroquine (which assists membrane permeation). The transfection efficiencies can be understood in terms of both the DNA affinities of the dendrons ( $\mathbf{G} \mathbf{2}>\mathbf{G} \mathbf{1}>\mathbf{G} \mathbf{0}$ ) and the fact that $\mathbf{G} \mathbf{2}$ shows some toxicity when administered in combination with DNA and chloroquine. The development of structure-activity relationships in the area of gene transfection is a goal of considerable importance in the field of gene therapy (28).

However, perhaps the most important observation from this study is that the dendrons exhibit negligible toxicities, either in their own right, or in the presence of DNA. This is an important first step in the development of potential vectors for application in gene therapy. It is also encouraging that the dendritic systems can be encouraged to transfect under certain conditions (i.e., addition of chloroquine to enable endosomal escape). We therefore believe that these systems have significant potential for application as the DNA binding subunit within more complex constructs designed for targeted gene therapy. However, this study has made clear that further synthetic modification of the basic dendron structure will be required, to enhance the transfection efficiencies of the nontoxic dendritic building blocks. Work targeting this goal is currently in progress within our laboratories, and we hope to report dendritic vectors for gene therapy applications, with significantly enhanced transfection efficiencies, in due course.

\section{Acknowledgment}

We gratefully acknowledge financial support from the EPSRC and Syngenta (J.G.H.) and a generous scholarship from the Worldwide Universities Network (WUN) which allowed J.G.H. to visit the laboratories in Illinois. Finally, we acknowledge financial support from the Erasmus-Socrates scheme (M.A.K.).

This article references 28 other publications.

1. (1) (a) Verma, I. M., and Somia, N. (1997) Gene therapy - promises, problems and prospects. Nature 389, 239-242. 
(b) Luo, D., and Saltzman, W. M. (2000) Enhancement of transfection by physical concentration of DNA at the cell surface. Nature Biotechnol. 18, 33-37.

(c) Demeneix, B., Hassani, Z., and Behr, J.-P. (2004) Towards multifunctional synthetic vectors. Curr. Gene Ther. 4, 445-455.

2. (2) (a) Gregorevic, P., and Chamberlain, J. S. (2003) Gene therapy for muscular dystrophy -a review of promising progress. Exp. Opin. Biol. Ther. 3, 803-814.

3. (3) (a) Ferrari, S., Geddes, D. M., and Alton, E. W. F. W. (2002) Barriers to and new approaches for gene therapy and gene delivery in cystic fibrosis. Adv. Drug. Delivery Rev. 54, 1373-1393.

(b) Sangiuolo, F., D'Apice, M. R., Gambardella, S., Di Daniele, N., and Novelli, G. (2004) Toward the pharmacogenomics of cystic fibrosis - an update. Pharmacogenomics 5 , 861-878.

(c) Kinsey, B. M., Densmore, C. L., and Orson, F. M. (2005) Nonviral gene delivery to the lungs. Curr. Gene Ther. 5, 181-194.

4. (4) (a) Hunt, K. K., and Vorburger, S. A. (2002) Hurdles and hopes for cancer treatment. Science 297, 415-416.

(b) Fang, B. L., and Roth, J. A. (2003) Tumor-suppressing gene therapy. Cancer Biol. Ther. 2, S115-S121.

(c) Scanlon, K. J. (2004) Cancer gene therapy: Challenges and opportunities. Anticancer Res. 24, 501-504.

(d) Vassaux, G., and Martin-Duque, P. (2004) Use of suicide genes for cancer gene therapy: Study of the different approaches. Exp. Opin. Biol. Ther. 4, 519-530.

(e) Schatzlein, A. G. (2001) Nonviral vectors in cancer gene therapy: Principles and progress. Anticancer Drugs 12, 275-304.

5. (5) (a) Fanning, G., Amado, R., and Symonds, G. (2003) Gene therapy for HIV/AIDS: The potential for a new therapeutic regimen. J. Gene Med. 5, 645-653.

(b) Wolkowicz, R., and Nolan, G. P. (2005) Gene therapy progress and prospects: Novel gene therapy approaches for AIDS. Gene Ther. 12, 467-476.

6. (6) Tomanin, R., and Scarpa M. (2004) Why do we need new gene therapy viral vectors? Characteristics, limitations and future perspectives of viral vector transduction. Curr. Gene Ther. 4, 357-372.

7. (7) Behr, J.-P. (1993) Synthetic Gene-Transfer Vectors. Acc. Chem. Res. 26, 274-278.

8. (8) Martin, B., Sainlos, M., Aissaoui A., Oudrhiri, N., Hauchecorne, M., Vigneron, J.-P., Lehn, J.-M., and Lehn, P. (2005) The design of cationic lipids for gene delivery. Curr. Pharm. Des. 11, 375-394.

9. (9) (a) Han, S., Mahato, R. I., Sung, Y. K., and Kim, S. W. (2000) Development of biomaterials for gene therapy. Mol Ther. 2, 302-317. 
(b) Merdan, T., Kopecek, J., and Kissel, T. (2002) Prospects for cationic polymers in gene and oligonucleotide therapy against cancer. Adv. Drug. Delivery Rev. 54, 715-758.

(c) Pack, D. W., Hoffman, A. S., Pun, S., and Stayton, P. S., Design and development of polymers for gene delivery. (2005) Nature Rev. Drug Discovery 4, 581-593.

10. (a) Dennig, J. (2003) Gene transfer in eukaryotic cells using activated dendrimers. Top. Curr. Chem. 228, 227-236.

(b) Stiriba, S. E., Frey, H., and Haag, R. (2002) Dendritic polymers in biomedical applications: From potential to clinical use in diagnostics and therapy. Angew. Chem., Int. Ed. 41, 1329-1334.

(c) Smith, D. K., Hirst, A. R., Love, C. S., Hardy, J. G., Brignell, S. V., and Huang, B. (2005) Selfassembly using dendritic building blocks - towards controllable nanomaterials. Prog. Polym. Sci. 30, 220-293.

11. (11) (a) Haensler, J., and Szoka, F. C. (1993) Polyamidoamine cascade polymers mediate efficient transfection of cells in culture. Bioconjugate Chem. 4, 372-379.

(b) Kukowska-Latallo, J. F., Bielinska, A. U., Johnson, J., Spindler, R., Tomalia, D. A., and Baker, J. R. (1996) Efficient transfer of genetic material into mammalian cells using Starburst polyamidoamine dendrimers. Proc. Natl. Acad. Sci. U.S.A. 93, 4897-4902.

(c) Tang, M. X., Redemann, C. T., and Szoka Jr, F. C. (1996) In vitro gene delivery by degraded polyamidoamine dendrimers. Bioconjugate Chem. 7, 703-714.

[ACS Full Text $\odot$ ], [PubMed], [CAS]

(d) Tang, M. X., and Szoka, F. C. (1997) The influence of polymer structure on the interactions of cationic polymers with DNA and the morphology of the resulting complexes. Gene Ther. 4, 823-828.

(e) Turunen, M. P., Hiltunen, M. O., Ruponen, M., Virkamaki. L., Szoka, F. C., Urtti, A., and Yla Herttuala, S. (1999) Efficient adventitial gene delivery to rabbit carotid artery with cationic polymer-plasmid complexes. Gene Ther. 6, 6-11.

(f) Ottaviani, M. F., Furini, F., Casini, A., Turro, N. J., Jockusch, S., Tomalia, D. A., and Messori, L. (2000) Formation of supramolecular structures between DNA and starburst dendrimers studied by EPR, CD, UV, and melting profiles. Macromolecules 33, 7842-7851.

(g) Bielinska, A. U., Chen, C. L., Johnson, J., and Baker, J. R. (1999) DNA complexing with polyamidoamine dendrimers: Implications for transfection. Bioconjugate Chem. 10, 843-850.

12. (12) (a) Luo, D., Haverstick, K., Belcheva, N., Han, E., and Saltzman, W. M. (2002) Poly(ethylene glycol)-conjugated PAMAM dendrimer for biocompatible, high-efficiency DNA delivery. Macromolecules 35, 3456-3462.

(b) Lee, J. H., Lim, Y. B., Choi, J. S., Lee, Y., Kim, T.-i., Kim, H. J., Yoon, J. K., Kim, K., and Park, J. S. (2003) Polyplexes assembled with internally quaternized PAMAM-OH dendrimer and 
plasmid DNA have a neutral surface and gene delivery potency. Bioconjugate Chem. 14, 1214-1221.

13. (13) (a) Zinselmeyer, B. H., Mackay, S. P., Schatzlein, A. G., and Uchegbu, I. F. (2002) The lower-generation polypropyleneimine dendrimers are effective gene-transfer agents. Pharm. Res. 19, 960-967.

(b) Lim, Y. B., Kim, T., Lee, J. W., Kim, S. M., Kim, H. J., Kim, K., and Park, J. S. (2002) Selfassembled ternary complex of cationic dendrimer, cucurbituril, and DNA: Noncovalent strategy in developing a gene delivery carrier. Bioconjugate Chem. 13, 1181-1185.

14. (14) (a) Ohsaki, M., Okuda, T., Wada, A., Hirayama, T., Niidome, T., and Aoyagi, H. (2002) In vitro gene transfection using dendritic poly(I-lysine). Bioconjugate Chem. 13, 510-517.

(b) Okuda, T., Kidoaki, S., Ohsaki, M., Koyama, Y., Yoshikawa, K., Niidome, T., and Aoyagi, H. (2003) Time-dependent complex formation of dendritic poly(I-lysine) with plasmid DNA and correlation with in vitro transfection efficiencies. Org. Biomol. Chem. 1, 1270-1273.

(c) Okuda, T., Sugiyama, A., Niidome, T., and Aoyagi, H. (2004) Characters of dendritic poly(Ilysine) analogues with the terminal lysines replaced with arginines and histidines as gene carriers in vitro. Biomaterials 25, 537-544.

(d) Vlasov, G. P., Korol'kov, V. I., Pankova, G. A., Tarasenko, I. I., Baranov, A. N., Glazkov, P. B., Kiselev, A. V., Ostapenko, O. V., Lesina, E. A., and Baranov, V. S. (2004) Lysine dendrimers and their starburst polymer derivatives: Possible applications for DNA compaction and in vitro delivery of genetic constructs. Russ. J. Bioorg. Chem. 30, 12-20.

(e) Choi, J. S., Lee, E. J., Choi, Y. H., Jeong, Y. J., and Park, J. S. (1999) Poly(ethylene glycol)block-poly(I-lysine) dendrimer: Novel linear polymer/dendrimer block copolymer forming a spherical water-soluble polyionic complex with DNA. Bioconjugate Chem. 10, 62-65.

(f) Choi, J. S., Joo, D. K., Kim, C. H., Kim, K., and Park, J. S. (2000) Synthesis of a barbell-like triblock copolymer, poly(l-lysine) dendrimer-block-poly(ethylene glycol)-block-poly(l-lysine) dendrimer, and its self-assembly with plasmid DNA. J. Am. Chem. Soc. 122, 474-480.

15. (15) Joester, D., Losson, M., Pugin, R., Heinzelmann, H., Walter, E., Merkle, H. P., and Diederich, F. (2003) Amphiphilic dendrimers: Novel self-assembling vectors for efficient gene delivery. Angew. Chem., Int. Ed. 42, 1486-1490.

16. (16) (a) Blagborough, I. S., Geall, A. J., and Neal, A. P. (2003) Polyamines and novel polyamine conjugates interact with DNA in ways that can be exploited in non-viral gene therapy. Biochem. Soc. Trans. 31, 397-406.

(b) Remy, J.-S., Abdallah, B., Zanta, M. A., Boussif, O., Behr, J.-P., and Demeneix, B. (1998) Gene transfer with lipospermines and polyethylenimines. Adv. Drug. Delivery Rev. 30, 85-95.

(c) Geall, A. J., Eaton, M. A. W., Baker, T., Catterall, C., and Blagborough, I. S. (1999) The regiochemical distribution of positive charges along cholesterol polyamine carbamates plays significant roles in modulating DNA binding affinity and lipofection. FEBS Lett. 459, 337-342.

(d) Ronsin, G., Perrin, C., Guédat, P., Kremer, A., Camilleri, P., and Kirby, A. J. (2001) Novel spermine-based cationic gemini sufactants for gene delivery. Chem. Commun. 2234-2235. 
(e) Geall, A. J., Al-Hadithi, D., and Blagborough, I. S. (2002) Efficient calf thymus DNA condensation upon binding with novel bile acid polyamine amides. Bioconjugate Chem. 13, 481-490.

(f) Boulanger, C., Di Giorgio, C., Gaucheron, J., and Vierling, P. (2004) Transfection with fluorinated lipoplexes based on new fluorinated cationic lipids and in the presence of a bile salt surfactant. Bioconjugate Chem. 15, 901-908.

(g) Dewa, T., leda, Y., Morita, K., Wang, L., MacDonald, R. C., lida, K., Yamashita, K., Oku, N., and Nango, M. (2004) Novel polyamine-dialkyl phosphate conjugates for gene carriers. Facile synthetic route via an unprecedented dialkyl phosphate. Bioconjugate Chem. 15, 824-830.

17. (17) Behr, J. P., Demeneix, B. A., Loeffler, J. P., and Perez-Mutul, J. (1989) Efficient gene transfer into mammalian primary endocrine-cells with lipopolyamine-coated DNA. Proc. Natl. Acad. Sci. U.S.A. 86, 6982-6986.

18. (18) (a) Lee, E. R., Marshall, J., Siegel, C. S., Jiang, C., Yew, N. S., Nichols, M. R., Nietupski, J. B., Ziegler, R. J., Lane, M., Wang, K. X., Scheule, R. K., Harris, D. J., Smith, A. E., and Cheng, S. H.; (1996) Detailed analysis of structures and formulations of cationic lipids for efficient gene transfer to the lung. Hum. Gene Ther. 7, 1701-1717.

(b) Cockett, M. I. (1999) Technology evaluation: cystic fibrosis therapy, Genzyme. Curr. Opin. Mol. Ther. 1, 279-283.

19. (19) Byk, G., Dubertret, C., Escriou, V., Frederic, M., Jaslin, G., Rangara, R., Pitard, B., Crouzet, J., Wils, P., Schwartz, B., and Scherman, D.(1998) Synthesis, activity and structure-activity relationship studies of novel cationic lipids for DNA transfer. J. Med. Chem. 41, 224-235.

20. (a) Tabor, C. W., and Tabor, H. (1984) Polyamines. Annu. Rev. Biochem. 740-790.

(b) Vijayanathan, V., Thomas, T., Shirahata, A., and Thomas, T. J. (2001) DNA condensation by polyamines: A laser light scattering study of structural effects. Biochemistry 40 , 13644-13651.

(c) Vijayanathan, V., Lyall, J., Thomas, T., Shirahata, A., and Thomas, T. J. (2005) Ionic, structural, and temperature effects on DNA nanoparticles formed by natural and synthetic polyamines. Biomacromolecules 6, 1097-1103.

21. (21) (a) Korolev, N., Lyubartsev, A. P., Nordenskiöld, L., and Laaksonen, A. (2001) Spermine: An "invisible" component in the crystals of B-DNA. A grand canonical Monte Carlo and molecular dynamics simulation study. J. Mol. Biol. 308, 907-917.

(b) Burak, Y., Ariel, G., and Andelman, D. (2004) Competition between condensation of monovalent and multivalent ions in DNA aggregation. Curr. Opin. Colloid Interface Sci. 9, 53-58.

22. (22) Kostiainen M. A., Hardy, J. G., and Smith, D. K. (2005) High-affinity multivalent DNA binding by using low-molecular-weight dendrons. Angew. Chem., Int. Ed. 44, 2556-2559. 
23. (23) (a) Newkome, G. R., and Lin, X. (1991) Symmetrical, 4-directional, poly(ether amide) cascade polymers. Macromolecules 24, 1443-1444.

(b) Newkome, G. R., Lin, X., and Weis, C. D. (1991) Polytryptophan terminated dendritic macromolecules. Tetrahedron: Asymmetry 2, 957-960.

(c) Young, J. K., Baker, G. R., Newkome, G. R., Morris, K. F., and Johnson Jr., C. S. (1994) Smart cascade polymers - modular synthesis of 4-directional dendritic macromolecules with acidic, neutral or basic terminal groups and the effect of $\mathrm{pH}$ changes on their hydrodynamic radii. Macromolecules 27, 3464-3471.

(d) Nierengarten, J.-F., Habicher, T., Kessinger, R., Cardullo, F., Diederich, F., Gramlich, V., Gisselbrecht, J.-P., Boudon, C., and Gross, M. (1997) Macrocyclization on the fullerene core: Direct regio- and diastereoselective multi-functionalization of [60]fullerene, and synthesis of fullerene-dendrimer derivatives. Helv. Chim. Acta 80, 2238-2276.

(e) Cardona, C. M., Gawley, R. E., and Gawley, C. (2002) An improved synthesis of a trifurcated Newkome-type monomer and orthogonally protected two-generation dendrons. J. Org. Chem. 67, 1411-1413.

24. (24) (a) Azzam, T., Eliyahu, H., Makovitzki, A., Linial, M., and Domb, A. J. (2004) Hydrophobized dextran-spermine conjugate as potential vector for in vitro gene transfection. J. Controlled Release 96, 309-323.

(b) Hosseinkhani, H., Azzam, T., Tabata, Y., and Domb, A. J. (2004) Dextran-spermine polycation: An efficient nonviral vector for in vitro and in vivo gene transfection. Gene Ther. 11, 194-203.

(c) Eliyahu, H., Makovitzki, A., Azzam, T., Zlotkin, A., Joseph, A., Gazit, D., Barenholz, Y., and Domb, A. J. (2005) Novel dextran-spermine conjugates as transfecting agents: comparing water-soluble and micellar polymers. Gene Ther. 12, 494-503.

25. (25) Stevens, M. G., and Olsen, S. (1993) Comparative analysis of using MTT and XTT in colorimetric assays for quantitating bovine neutrophil bactericidal activity. J. Immunol. Methods 157, 225-231.

26. (26) (a) Dunlap, D. D., Maggi, A., Soria, M. R., and Monaco, L. (1997) Nanoscopic structure of DNA condensed for gene delivery. Nucleic Acids Res. 25, 3095-3101.

(b) Liu, G., Molas, M., Grossmann, G. A., Pasumarthy, M., Perales, J. C., Cooper, M. J., and Hanson, R. W. (2001) Biological properties of poly-I-lysine -DNA complexes generated by cooperative binding of the polycation. J. Biol. Chem. 276, 34379-34387.

27. (27) (a) Felgner, J. H., Kumar, R., Sridhar, C. N., Wheeler, C. J., Tsai, Y. J., Border, R., Ramsey, P., Martin, M., and Felgner, P. L. (1994) Enhanced gene delivery and mechanism studies with a novel series of cationic lipid formulations. J. Biol. Chem. 269, 2550-2561.

(b) Erbacher, P., Roche, A. C., Monsigny, M., and Midoux, P. (1996) Putative role of chloroquine in gene transfer into a human hepatoma cell line by DNA/lactosylated polylysine complex. Exp. Cell. Res. 225, 186-194. 
(c) Forrest, M. L., and Pack, D. W. (2002) On the kinetics of polyplex endocytic trafficking: Implications for gene delivery vector design. Mol. Ther. 6, 57-66.

28. (28) McGregor, C., Perrin, C., Monck, M., Camilleri, P., and Kirby, A. J. (2001) Rational approaches to the design of cationic gemini surfactants for gene delivery. J. Am. Chem. Soc. $123,6215-6220$. 